\title{
REFLECTIONS ON URBAN SPRAWL, SMART GROWTH, AND THE FIFTH AMENDMENT
}

\author{
TIMOTHY J. DOWLING ${ }^{\dagger}$
}

The purpose of this essay is modest and twofold. First, I hope to show that the policy debate regarding whether urban sprawl is a serious problem should be over and largely is over. Legitimate disagreement exists regarding the cure and the proper roles of federal, state, and local governments in addressing sprawl, but it is no longer reasonable to deny sprawl's existence.

Second, I argue that efforts to combat sprawl are entirely consistent with longstanding traditions regarding appropriate regulation of land use, as well as the Takings Clause of the Fifth Amendment. ${ }^{1}$ Those who argue that courts should constrain smart growth initiatives through an activist application of the Takings Clause threaten not only our constitutional structure, but also the very property rights they purport to champion.

\section{MUCH ADO ABOUT NOTHING?}

G.K Chesterton once observed that it is sometimes difficult to defend a proposition of which you are entirely convinced. If you were asked, for example, why civilization is preferable to savagery, you might look wildly around, pointing at object after object, and frantically but vaguely respond: "Why, there is that bookcase... and pianos ... and policemen." In Chesterton's words, the "very multiplicity of proof which ought to make reply overwhelming makes reply impossible."

† Chief Counsel, Community Rights Counsel, a non-profit law firm in Washington, D.C. that assists local governments in defending against challenges to land-use controls and other community protections. Portions of this essay are derived from a draft of DOUglas T. KENDALL, TIMOTHY J. DOWLING, \& ANDREW W. SCHWARTZ, TAKINGS LMTIGATION HANDBOOK: DEFENDING TAKINGS CHALLENGES TO LAND USE REGULATIONS (forthcoming 2000).

${ }^{1}$ U.S. CONST. amend. V (" $[N]$ or shall private property be taken for public use, without just compensation.").

${ }^{2}$ GIIBERT K GHESTERTON, ORTHODOXY 83 (Image Books 1959) (1908).

${ }^{3} I d$. 
The sprawl debate sometimes suffers from the difficulty of proving the obvious. When skeptics suggest that concerns about sprawl are largely dust and nonsense, it is hard to know where to begin. The debate sometimes lacks precision because urban sprawl threatens so much: quality of life (particularly in our poorest neighborhoods), prime farmland, the environment, our historic and cultural heritage, and our sense of community.

Because sprawl's harmful effects are all-pervasive, there is a danger of forgetting what life was like without it. Over time, we might unthinkingly come to accept a ninety-minute daily commute, a smoggy horizon, lifeless central cities, and bloated property taxes as the natural order of things. Like the skeptical fish that questions whether there is any water in the tank, skeptics try to use sprawl's very pervasiveness to their advantage.

Sprawl unquestionably has an I-know-it-when-I-see-it quality to it. ${ }^{5}$ As with pornography, however, the difficulty in defining urban sprawl is no argument against attempting to control it. As we work to find solutions, a common definition is emerging - a definition that focuses the debate on low-density, land-consuming, automobile-dependent, haphazard, non-contiguous (or "leapfrog") development on the fringe of settled areas, often near a deteriorating central city or town, that intrudes into rural or other undeveloped areas. ${ }^{6}$

The problem is not growth per se, but dysfunctional growth. The solution is not no growth, but smart growth achieved by directing development back to central cities and other areas that yield sustainable communities. Tax incentives, brownfield redevelopment, elimination of sprawl-enhancing subsidies, urban growth boundaries, transferable

${ }^{4}$ See Bill Bishop, Urban Sprawl Makes Comeback, LeXINGTON-HERALD-LEADER, Mar. 14, 1999, at F1 ("Sprawl doesn't hurt anybody... . [It] is the American dream.").

${ }^{5}$ See Richard Moe, The Sprawling of America: Federal Policy Is Part of the Problem; Can It Be Part of the Solution?, Address Before the National Press Club (Jan. 22, 1999), in National Trust for Historic Preservation (visited Nov. 6, 1999) <www.nthp.org/main/abouttrust/sprawling.htm> (stating that sprawl "reminds me of Justice Stewart's remark about pornography: It's hard to define, but you know it when you see it").

${ }^{6}$ See, e.g., National Ass'N Of Local Gov't ENVTL. Prof'Ls, Profiles of Business LEADERSHIP ON SMART GROWTH: NEW PARTNERSHIPS DEMONSTRATE THE ECONOMIC BENEFITS OF REDUCING SPRAWL 8 (1999) [hereinafter BUSINESS LEADERSHIP ON SMART GROWTH] (defining sprawl as "low-density, discontinuous, automobile-dependent, new development on the fringe of settled areas"); TRANSIT COOP. RESEARCH PROGRAM, REPORT 39: THE COSTS OF SPRAWI-REVISITED 6-8 (1998) (offering a multifaceted definition of sprawl which focuses on low density, noncontiguous or leapfrog development patterns, consumption of ex-urban lands, reliance on the automobile, and the lack of integrated land-use planning). 
development rights, and many other initiatives comprise the smart growth agenda.

Evidence of sprawl surrounds us. For years, sprawl consumed nearly six million acres of farmland annually, ${ }^{7}$ and we continue to lose an estimated one million acres each year. ${ }^{8}$ In central California, sprawl threatens to destroy more than 3.6 million acres of our most. productive farmland in the first half of this century. ${ }^{9}$ According to the American Farmland Trust, $80 \%$ of our fruits, vegetables, and dairy products are "in the path of sprawling development."

Sprawl leads to excessive dependence on automobiles, which imposes enormous costs and degrades our quality of life. The average daily round-trip commute for workers in Atlanta is 36.5 miles. ${ }^{11}$ The average speed on Los Angeles freeways is expected to fall to eleven miles per hour during the next decade. ${ }^{12}$ In Washington, D.C., area residents waste about seventy-six hours each year in traffic jams at a cost of about $\$ 1260$ per person. ${ }^{13}$ Nationwide, the price tag for lost time and fuel due to sprawl-exacerbated congestion is $\$ 72$ billion per year. ${ }^{14}$ This congestion is literally driving us crazy, with steadily increasing road-rage incidents claiming more than 200 lives in recent years. $^{15}$

7 See Julian Conrad Juergensmeyer, Farmland Preservation: A Vital Agricultural Issue for the 1980's, 21 WASHBURN L.J. 443, 444 (1982) (reporting that from 1954 to 1974, suburban growth replaced about 119 million acres of farmland).

${ }^{8}$ See Open Space and Environmental Quality: Hearings Before the Senate Comm. on. Env'l and Public Works, 106th Cong. 155 (1999) (statement of Ralph Grossi, President, American Farmland Trust) [hereinafter Grossi Testimony] (noting that a 1997 American Farmland Trust study "found that over the past decade 1,000,000 acres of farmland were lost to urban uses each year").

9 See Moe, supra note 5 ('It's estimated that over the next 45 years, sprawl in the Central Valley of California will affect more than 3.6 million acres of America's most productive farmland.").

${ }_{11}$ Grossi Testimony, supra note 8, at 155.

11 See Daniel Pedersen et al., Sprawling, Sprawling, NEwSWEER, July 19, 1999, at 24, 25 ("Atlantans drive 36.5 daily miles round trip to work, more than Dallas's 29.5 and Los Angeles's 20.5."). time).

${ }_{12}$ See Moe, supra note 5 (arguing that sprawl results in commuters losing valuable

${ }^{13}$ See Alan Sipress, No Headway in Traffic Woes, WASH. POST, Nov. 17, 1999, at B1 (citing a report by the Texas Transportation Institute, which ranked traffic in Washington, D.C. as the second worst nationally).

${ }_{14}$ See id. (reporting the results of a Texas A\&M study).

${ }^{15}$ See Alan Sipress, Death at an Alabama Exit, Road Rage Engulfs Two Women and a Suburb, WASH. POST, Nov. 16, 1999, at Al (reporting that according to an AAA Foundation for Traffic Safety study, road-rage incidents increased nearly sixty percent and resulted in 218 deaths from 1991 to 1996). 
Sprawl imposes burdensome infrastructure costs. One study estimates that the cost of providing services in outlying areas is at least twice the cost of servicing new development located near existing facilities. ${ }^{16}$ In Maine, for example, the cost of education, roads, and police increased by $\$ 1300$ per household during the 1980 s, and sprawl was a major contributor. ${ }^{17}$

Try as they might, skeptics cannot credibly dismiss concerns about sprawl as the rant of environmental extremists. Indeed, business leaders are among the most effective voices for smart growth. Citing the enormous costs of sprawl in California, a 1995 landmark report sponsored by the Bank of America found that "unchecked sprawl has shifted from an engine of California's growth to a force that now threatens to inhibit growth and degrade the quality of our life." The report concludes that sprawl contributes to, among other ills, decreased employee productivity, higher business costs and taxes, and a decreased urban tax base. ${ }^{19}$

Other industry executives agree. The Atlanta Chamber of Commerce has established a Smart Growth Partnership with the Urban Land Institute and The Georgia Conservancy because traffic congestion threatens Atlanta's economic vitality. ${ }^{20}$ In Silicon Valley, industry leaders are promoting smart growth to attract highly skilled workers to leading high-tech companies. ${ }^{21}$ Business executives in northwest Michigan are pursuing smart growth to preserve the natural environ-

${ }^{16}$ See Robert H. FreIIICH, From SPRAWL to SMart Growth: SUCCESSFUl Legal, PlanNING, AND ENVIRONMENTAL SYSTEMS 23-24 (1999) (citing a recent Urban Land Institute study).

${ }^{17}$ See MAINe STATe PlanNINg OfFice, The Cost OF SPRAwL 10 (1997), available at <http://www.state.me.us/spo/files/sprawl.pdfs ("Maine state and local government spending in ... three areas alone-education, roads, and police-increased in real dollars by $\$ 637$ million during the 1980 's, a total of over $\$ 1,300$ per Maine household. ... [I] t is beyond dispute that the spreading out of Maine families is a major contributing factor to the overall increase.").

${ }^{18}$ BEYOND SPRAWL: NEW PATTERNS OF GROWTH TO FIT CALIFORNIA 1 (1995) (sponsored by Bank of America, California Resources Agency, Greenbelt Alliance, and the Low Income Fund).

${ }^{19}$ See id. at 6 (cataloguing the "cost of sprawl" on taxpayers, businesses, residents of new suburbs, residents of cities and older suburbs, farmers, and the environment).

${ }^{20}$ See BuSINESS LEADERSHIP ON SMART GROWTH, supra note 6, at 13-14 ("The Chamber [of Commerce] recently formed a Smart Growth Partnership with the local district council of the Urban Land Institute and The Georgia Conservancy to promote smart growth, and it continues to advocate a more balanced transportation system in the region.").

${ }^{21}$ See id. at 1415 (noting the use of smart growth initiatives "to preserve the region's quality of life"). 
ment and to protect the area's tourism industry. ${ }^{22}$

The people who live with sprawl every day recognize it as a serious failure of public policy. Nationwide polls show strong public support for the protection of open space. ${ }^{23}$ In 1998 , voters weighed in on more than 240 ballot initiatives designed to control sprawl, and they approved more than $70 \%$ of them. ${ }^{24}$ In one of the fastest growing counties in the nation, smart growth candidates recently prevailed in every contested county supervisor race. ${ }^{25}$ Thirty-four governors hailed open space protection and other smart growth initiatives in their 1998 inaugural or "state of the state" addresses. ${ }^{26}$ In the Commonwealth of Virginia, hardly a hotbed of radical activism, most people believe urban sprawl is destroying their cultural heritage and quality of life, and about $70 \%$ favor smart growth. ${ }^{27}$

Skeptics respond that only a small percentage of the United States is developed. With so much open space available, they contend, the anti-sprawl movement must perforce be a subterfuge to expand government power at the expense of individual freedom. ${ }^{28}$ Those who make this argument would have more credibility if they resided in Death Valley or the other vast, uninhabitable terrain they include in their calculation.

More to the point, our concentrated population patterns cannot

${ }^{22}$ See id. at 14 (reporting on the launch of a land use management campaign "to promote alternative patterns of development").

${ }^{23}$ See Polls Show Sirong Support for Open Space, ENVIRONMENTAL NEWS NETWORK, July 23, $1999<$ http://www.enn.com/news/enn-stories/1999/07/072399/luntzpoll_4527. asp> (stating that many Americans ranked the conservation of parks and open space "above other major congressional priorities [in 1999]").

24 See BUSINESS LEADERSHIP ON SMART GROWTH, supra note 6, at 10.

25 See Alan Sipress, N.Va.'s Message: Slow Development, WASH. POST, Nov. 3, 1999, at Al (reporting that in Loudoun County, which is absorbing about 1000 new residents every month, a slate of eight anti-sprawl candidates prevailed in every contested county supervisor race by "tapping popular frustration over roads increasingly glutted with traffic, schools spilling into makeshift classrooms and the relentless harvest of new subdivisions").

${ }_{26}$ See BUSINESS LEADERSHIP ON SMART GROWTH, supra note 6, at 10.

27 See National trust for historic Preservation, Ghatrenging SPRawl: ORGANIZATIONAL RESPONSES TO A NATIONAL PROBLEM 3 (Constance E. Beaumont ed., 1999) (stating that a January 1999 poll indicates that "70 percent of Republicans, and 68 percent of Democrats, in Virginia want to see growth and development better managed," and that "[56] percent of Virginia's voters believe that the Commonwealth's heritage and quality of life have become "a casualty to homogenized growth" (citation omitted)).

${ }^{28}$ Steven Hayward, Suburban Legends, NAT'L REV., Mar. 22, 1999, at 35 ("[T] he threat of sprawl is vastly overblown.... Developed land accounts for less than 5 percent of the total land area in the continental United States."). 
plausibly be used to justify the unplanned, myopic growth that is destroying our central cities, prime farmland, and environment. The macro-statistics used by opponents of smart growth gloss over distinctions between the quality of the land we are losing and the land that remains. To be sure, we can convert some forestland and rangeland to cropland, but the highly productive, prime farmland we are losing today will be gone forever. ${ }^{29}$ The same holds true for environmentally sensitive land that falls victim to sprawl.

Skeptics also argue that the market is self-correcting because periods of great open space loss are sometimes followed by a period of reduced loss. ${ }^{30}$ Recently released statistics show just the opposite, with almost sixteen million acres of forest, cropland, and open space on private land lost to development from 1992 to 1997, more than double the annual loss rate experienced from 1982 to $1992 .{ }^{31}$ Moreover, even if accurate in isolated locations, this argument disregards the obvious truth that the rate of open space loss sometimes decreases in particular areas because once open space is lost, there is less to lose. To cite but one example, California has lost ninety percent of its original wetlands and ninety-five percent of its coastal wetlands. ${ }^{32}$ That the rate of wetlands and open space loss might be falling in certain areas is not

29 See Grossi Testimony, supra note 8, at 155 .

The fact is that every year we continue to squander some of this nation's most valuable farmland with the expectation that this land can be replaced with imports, or with new technologies that promise to help maintain the productivity gains of the past half century. The reality is that we don't know whether new technologies will keep pace.

Id.; see also A. ANN SORENSEN ET AL., FARMING ON THE EDGE 2 (American Farmland Trust 1997) (noting that of the country's 181 “Major Land Resource Areas, 70 percent had high quality farmland in the same areas where rapid development was occurring").

See Samuel R. Staley, The Sprawing of america: In Defense of the DyNamic CiTy 14-17 (Reason Public Policy Institute Policy Study No. 251, 1999) ("[T] he most rapid rate of suburbanization occurred between 1920 and 1950. . . From 1970 to 1982 , the median sprawl index for the nation was 5.03. By 1982 to 1992 , the national median had fallen to 2.75. Individual states experienced substantial volatility from one period to the next." (citations omitted)).

${ }_{31}$ See National RESOURCES CONSERVATION SERV., U.S. DEP'T OF AGRIC., 1997 NATIONAL RESOURCES INVENTORY HIGHLIGHTS 1 (1999) ("[F]rom 1992-97 more land was developed (nearly 16 million acres) than during 1982-92 (more than 13 million acres).... From 1992-97, the national rate of development more than doubled to 3 million acres per year.").

${ }^{32}$ See California Wetlands Information System, Califormia's Valuable Wetlands (visited Oct. 26, 1999) <http://www.ceres.ca.gov/wetlands/introduction/values.html> ("California today has only 10 percent of the wetlands that existed before settlement by Europeans. ... Only 5 percent of the state's coastal wetlands remain intact."). 
necessarily cause to cheer. ${ }^{33}$

One skeptic suggests that sprawl actually enhances air quality, arguing that although sprawl has increased since the 1970s, levels of carbon monoxide, lead, and other air pollutants have fallen. ${ }^{34} \mathrm{~A}$ better example of the post hoc, ergo propter hoc fallacy is difficult to imagine, for this reasoning attributes air quality improvements to sprawl simply because they followed (or coincided with) sprawl, with no accounting for the federal ban on leaded gasoline, more stringent air quality controls, and the many other factors that led to those air quality improvements. Moreover, emissions of one key precursor to groundlevel ozone and smog, nitrogen oxide, increased $11 \%$ from 1970 to $1997,{ }^{35}$ and the national average ozone level increased five percent in $1998 .^{36}$ Although today's automobiles are more than $90 \%$ cleaner than the cars of the $1970 \mathrm{~s},{ }^{37}$ millions of Americans still breathe unhealthy air in part because we drive more than twice as many miles as we did in $19700^{38}$

${ }^{33}$ See Lois J. Schiffer \& Jeremy D. Heep, Forests, Wetlands and the Superfund: Three Examples of Environmental Protection Promoting Jobs, 22 J. CORP. L. 571, 589 (1997) ("In California alone, according to a University of California at Berkeley study, the quantifiable benefits of the state's remaining 454,000 acres of wetlands are worth $\$ 10$ billion annually.").

${ }^{34}$ See STALEY, supra note 30, at 50 ("Nitrogen oxides, hydrocarbons, carbon monoxide, and lead pollutants often associated with automobile use have fallen consistently since the 1970s." (footnote omitted)).

${ }^{35}$ See U.S. Environmental Protection Agency, National Air Quality and Emissions Trends Report, 1997, Fact Sheet (EPA Doc. No. 454/R-98-016) (visited Oct. 27, 1999) <http://www.epa.gov/oar/aqtrnd97/trendsfs.html> (stating that "while air quality has improved for all of the 'criteria' pollutants, actual emissions of nitrogen oxides (NOx) between 1970 and 1997 increased 11 percent").

${ }^{36}$ See The Reauthorization of the Clean Air Act: Hearings Before the Subcomm. on Clean. Air, Wetlands, Private Property and Nuclear Safety of the Senate Comm. on Env't and Pub. Works, 106th Cong. (1999) (statement of Robert Perciasepe, Assistant Administrator, Office of Air and Radiation, U.S. Environmental Protection Agency) [hereinafter Perciasepe Testimony], available in <http://www.senate.gov/ epw/epa_1014.htm> ("The national average ozone level increased 5 percent in 1998.").

${ }^{37}$ See Reducing Sulfur in Gasoline and Diesel Fuel: Hearing Before the Subcomm. on Energy and Env't of the House Comm. on Science, 106th Cong. 11 (1999) (statement of Margo Oge, Director, Office of Mobile Sources, Office of Air and Radiation, U.S. Environmental Protection Agency) ("[T]oday's vehicles are over $90 \%$ cleaner than cars available twenty-five years ago....").

${ }^{33}$ See Perciasepe Testimony, supra note 36 ("From 1970 to $1997, \ldots$ the U.S. population has grown by $31 \%$, and the number of miles traveled by on-road vehicles (VMT) has increased by $127 \% . "$ ). 


\section{IS SMART GROWTH UN-AMERICAN?}

Opponents of smart growth argue that even if sprawl causes harm, this harm simply manifests the aggregation of individual decisions made in the marketplace. They contend that our traditions require us to respect these individual choices because they reflect "the American dream." $"$

Two responses are in order. First, sprawl does not reflect choices made in an unregulated marketplace but choices heavily influenced by huge government subsidies that encourage sprawl. Nearly eightyfive percent of federal transportation money "paves the way for sprawl." ${ }^{40}$ The federal tax code, floodplain insurance subsidies, government funding for expansion of water and sewer facilities, federal mortgage subsidies and guarantees, federal urban housing programs, gasoline prices that fail to recover external costs, and other subsidies have long skewed marketplace decisions. ${ }^{41}$

Some skeptics, while candidly acknowledging the existence of prosprawl subsidies, seem to suggest that smart growth advocates use them as a fig leaf to justify needless regulation. In fact, the bulk of the debate centers on these subsidies. Maryland's cutting-edge smart growth program now restricts state subsidies for roads, sewers, and schools to areas that will support sustainable communities. ${ }^{42}$ Milwaukee is reversing the pro-sprawl effects of the federal transportation subsidy by using that money to deconstruct a half-built section of city highway to make room for new homes and businesses. ${ }^{43}$ Many smart

${ }^{39}$ Bishop, supra note 4, at FI.

${ }^{40}$ Pietro S. Nivola, Make Way for Sprawl, WASH. Post, June 1, 1999, at A1.

${ }^{41}$ According to a recent survey of urban historians, planners, and architects by Professor Robert Fishman on behalf of the Fannie Mae Foundation, federal highway subsidies and federal mortgage subsidies ranked as the top two influences on American cities in the past fifty years. See Robert Fishman, The AmErican METropolis at CENTURY'S END: PAST AND FUTURE INFLUENCES 2 (1999 Fannie Mae Foundation Annual Housing Conference Survey) (copy on file with the University of Pennsylvania Law Review). The report concludes that "[t]he single most important 'message' of this [survey] is the overwhelming impact of the federal government on the American metropolis, especially through policies that intentionally or unintentionally promoted suburbanization and sprawl." Id. at 3.

${ }_{42}$ MD. CODE ANN., STATE FIN. \& PROC. §§ 5-7B-01 to 5-7B-10 (1999) (restricting state funding for new roads, sewers, and other infrastructure to areas designated for growth).

${ }^{43}$ See Timothy Egan, The Freeway, Its Cost, and 2 Cities' Destinies, N.Y. TIMES, July 14, 1999 , at Al ("[Milwaukee] plans to use more than $\$ 20$ million in Federal transportation money to tear down a half-built section of highway that was supposed to cut right through old Milwaukee."). 
growth advocates would declare victory if we simply eliminated prosprawl subsidies, or counterbalanced them with sufficient incentives and controls to draw people back to central cities.

Second, recent research by Professor John Hart demonstrates that land-use controls have a rich tradition in the United States. ${ }^{44}$ Colonial land-use regulation went far beyond the control of nuisances and included planning efforts remarkably similar to those used to combat modern-day sprawl. ${ }^{45}$

For example, the Massachusetts Bay Colony prohibited dwellings more than one-half mile from town meeting houses without approval by the court. ${ }^{46}$ Connecticut fashioned laws to address the depopulation of towns. ${ }^{47}$ Colonial land-use controls limited not only the amount, but also the sequence, of new development, much as modern smart growth initiatives seek to avoid "leapfrog development." These colonial regulations-"so numerous and varied, so widely distributed, that they cannot be viewed as anomalous" ${ }^{39}$-confirm that local landuse planning has roots deep in the American tradition.

\section{IS SMART GROWTH A TAKING?}

That land-use controls, including analogues to modern smart growth initiatives, are consistent with our historical traditions does not by itself show that they comport with the Takings Clause. To demonstrate the constitutionality of smart growth initiatives, we need first to examine the text, structure, and history of the Takings Clause.

The term "take" most naturally refers to an actual expropriation of property, and thus the text of the Takings Clause does not readily suggest application to mere restrictions on the use of property. ${ }^{50}$ The

${ }^{44}$ See John F. Hart, Colonial Land Use Law and Its Significance for Modern Takings Doctrine, 109 HARV. L. REV. 1252, 1253 (1996) (noting that land use was substantially regulated in colonial times).

${ }^{45}$ See id. at 1253 (concluding that "[c]ontrary to the conventional image of minimal land-use regulation, government in the colonial period often exerted extensive authority over private land for purposes unrelated to avoiding nuisance," including land-use controls related to population densities and aesthetics).

${ }^{46}$ See id. at 1273 (describing restrictions on locations of dwellings in the Massachusetts Bay Colony).

${ }^{47}$ See id. at 1275 (describing Connecticut's concern with optimizing population densities).

${ }_{48}^{4}$ See id. (describing controls on the sequence of development in the New Netherland Colony).

${ }^{49} I d$, at 1281 .

${ }^{50}$ See Fred BosSELMAN ET AL., ThE TAKING ISSUE 51 (1973) ("The word 'take' or- 
framers' original understanding of the Clause was consistent with this narrow, plain meaning. Although there is some disagreement over the framers' general views on property, there is much evidence that they believed the Takings Clause would prohibit only actual expropriations of private property. ${ }^{51}$

Even Justice Scalia, generally regarded as quite sympathetic to takings claimants, recognizes that the ratifying generation (and several succeeding generations) read the Clause as applying only to actual dispossessions of property. Writing for the majority in Lucas $v$. South Carolina Coastal Council, Justice Scalia stated that "early constitutional theorists did not believe the Takings Clause embraced regulations of property at all." ${ }^{52}$ Rather, "it was generally thought that the Takings Clause reached only a 'direct appropriation' of property... or the functional equivalent of a 'practical ouster of [the owner's] possession." ${ }^{53}$

Adhering to this original understanding, during the first several decades of takings jurisprudence, the Supreme Court steadfastly refused to extend the Clause beyond actual expropriations or physical occupations of property. For example, in the 1870 Legal Tender Cases, the Court stated:

[The Takings Clause] has always been understood as referring only to a direct appropriation, and not to consequential injuries resulting from the exercise of lawful power. It has never been supposed to have any bearing upon, or to inhibit laws that indirectly work harm and loss to individuals.... [I]t is not every hardship that is unjust, much less that is unconstitutional; and certainly it would be an anomaly for us to hold an

dinarily refers to the act of obtaining possession or control of property, and although there are many other usages of the word none of them seems descriptive of governmental regulation of the use of land.").

${ }^{51}$ See William Michael Treanor, The Original Understanding of the Takings Clause and the Political Process, 95 ColUM. L. REv. 782, 783 (1995) ("While the evidence of original intent is limited, it clearly indicates that the Takings Clause was intended to apply only to physical takings, and the early case law interpreted it and its state counterparts as not extending to government regulations."); John A. Humbach, "Taking" the Imperial Judiciary Seriously: Segmenting Property Interests and Judicial Revision of Legislative Judgments, 42 CATH. U. L. REV. 771, 776-77 (1993) (arguing that "interpreting the Takings Clause to limit regulation appears ahistorical").

${ }^{52} 505$ U.S. 1003, 1028 n.15 (1992) (observing that the Court's modern interpretation of the Takings Clause departs from the understanding of early constitutional theorists).

${ }^{53}$ Id. at 1014 (citations omitted) (describing the traditionally prevailing view of the Takings Clause prior to 1922). 
act of Congress invalid merely because we might think its provisions harsh and unjust.

To be sure, the Supreme Court subsequently applied the Takings Clause beyond actual expropriations, but expropriation has served as the critical benchmark for determining whether other government actions effect a compensable taking. In the first regulatory takings case, Pennsylvania Coal Co. v. Mahon, the Court held that Pennsylvania mining restrictions constituted an uncompensated taking of property because they had "very nearly the same effect for constitutional purposes as appropriating" the coal company's support estate, which Pennsylvania law recognized as a distinct and valuable property interest. $^{55}$ When the Court held that a government-compelled, permanent physical occupation of property constitutes a per se taking, it did so because such intrusions are the practical equivalent of an appropriation. $^{56}$ More recently, when the Court held that government action that deprives land of all economically viable use constitutes a per se taking, it again used expropriation as a benchmark, emphasizing that such action "is, from the landowner's point of view, the equivalent of a physical appropriation. ${ }^{157}$ Elsewhere, the Court has stated that its task in regulatory takings cases is "to distinguish the point at which regulation becomes so onerous that it has the same effect as an appropriation of the property through eminent domain or physical possession. ${ }^{\text {58 }}$

Because smart growth initiatives rarely (if ever) constitute the functional equivalent of an expropriation of property, courts consistently have rejected takings challenges to efforts to control sprawl. In the only Supreme Court case to mention sprawl, the Court gave smart growth a ringing endorsement in the face of a takings challenge, stating that it has "long ... been recognized as legitimate" for local governments to discourage "the premature and unnecessary conversion of open-space land to urban uses. ${ }^{, 59}$ The Court also gave its imprimatur to efforts to protect against "air, noise and water pollution, traffic

${ }^{54}$ Legal Tender Cases, 79 U.S. (12 Wall.) 457, 551-52 (1870).

55 260 U.S. 393, 414-15 (1992).

${ }^{56} \mathrm{See}$ Loretto v. Teleprompter Manhattan CATV Corp., 458 U.S. 419, 428-31 (1982) (discussing cases in which permanent physical occupation has been held to be a per se taking, based on the rationale that such occupation is the functional equivalent of an appropriation).

${ }^{57}$ Lucas, 505 U.S. at 1017.

${ }^{58}$ Williamson County Reg'l Planning Comm'n v. Hamilton Bank, 473 U.S. 172, 199 (1985).

${ }^{59}$ Agins v. City of Tiburon, 447 U.S. 255, 261 (1980). 
congestion, destruction of scenic beauty, disturbance of the ecology and environment, hazards related to geology, fire and flood, and other demonstrated consequences of urban sprawl., ${ }^{, 60}$ Lower courts have been similarly accommodating toward efforts to combat sprawl. ${ }^{61}$

In view of the text, structure, and history of the Takings Clause, as well as decades of regulatory takings jurisprudence, the suggestion that smart growth initiatives are unconstitutional requires considerable movement toward the absolutist notion of property rights espoused by Professor Richard Epstein, who would apply the Clause broadly to invalidate myriad government actions. ${ }^{62}$ For most constitutional scholars on both sides of the political spectrum, the severe conflict between Epstein's theories and the original understanding of the Takings Clause is sufficient by itself to warrant rejecting those theo-

Id. at 261 n.8.

61 See Christensen v. Yolo County Bd. of Supervisors, 995 F.2d 161, 164-66 (9th Cir. 1993) (rejecting a takings challenge and other constitutional challenges to a zoning agreement that "advances the policies of Yolo County to preserve prime agricultural land and to discourage urban sprawl"); Pompa Constr. Corp. v. City of Saratoga Springs, 706 F.2d 418, 422 (2d Cir. 1983) (rejecting a takings challenge to a zoning ordinance designed to conserve "land by discouraging premature development and avoid[ing] undisciplined and needless urban sprawl with its consequent municipal headaches"); Stansberry v. Holmes, 613 F.2d 1285, 1288 (5th Cir. 1980) ("The past decade has seen a growing popular acceptance of the notion that infinite uncontrolled growth often produces the unsightly sprawl that threatens to turn every major street into a neon commercial carnival."); Furey v. City of Sacramento, 592 F. Supp. 463, 471 \& n.10 (E.D. Cal. 1984) (rejecting a takings challenge to zoning designed to preserve open space and to control urban sprawl), affd 780 F.2d 1448 (9th Cir. 1986); Kent Island Joint Venture v. Smith, 452 F. Supp. 455, 457 \& n.4, 464 (D. Md. 1978) (rejecting takings and other challenges to land use regulation under a Maryland statute "intended as a 'tool whereby design and rationality can replace ... chaotic sprawl'" (quoting Smoke Rise, Inc. v. Washington Suburban Sanitary Comm'n, 400 F. Supp. 1369, 1381-83 (D. Md. 1975) (rejecting takings and other challenges to a Maryland antisprawl statute))); 2nd Roc-Jersey Assocs. v. Town of Morristown, 731 A.2d 1 (N.J. 1999) (rejecting takings and other constitutional challenges to efforts to address urban sprawl that diminished the vitality of traditional city centers); Golden v. Planning Bd. of Ramapo, 285 N.E.2d 291, 302-05 (N.Y. 1972) (rejecting takings and other challenges to urbanized tier controls on the timing and sequence of development designed to ensure the provision of adequate municipal facilities). The landmark Ramapo ruling, viewed by many as a watershed victory for growth management and smart growth protections, has been cited with approval by dozens of courts in the past 25 years. See FREIICH, supra note 16, at 63-64 (describing the tremendous success that Ramapo has had in the courts and listing specific venues in which it has been cited).

${ }^{62}$ See Richard EPSTEIN, TAIINGS: PRIVATE PROPERTY AND THE POWER OF EMINENT DOMAIN $x$ (1985) (asserting that the Takings Clause and parallel provisions "render constitutionally infirm or suspect many of the heralded reforms and institutions of the twentieth century: zoning, rent control, workers' compensation laws, transfer payments, progressive taxation"). 
ries. $^{63}$

Nevertheless, some commentators who oppose smart growth embrace Epstein's radical reading of the Takings Clause. They argue that a compensable taking occurs whenever community protections restrict land use or reduce property value. ${ }^{64}$ The only exception to their proposed compensation mandate is for land-use controls that address a nuisance. ${ }^{65}$ As Professor Joseph Sax has demonstrated, however, this approach conflicts with more than 150 years of Supreme Court precedent ${ }^{66}$ Members of the Court generally sympathetic to takings claims, such as Chief Justice Rehnquist and Justice Scalia, have joined opinions emphasizing that value loss, even severe value loss, is inadequate to establish a taking. ${ }^{67}$ The Court also expressly has repudiated the notion that takings liability turns on whether the challenged government action addresses a common law nuisance. ${ }^{68} \mathrm{Al}-$ though controls on nuisances are immune from takings liability because they are part of the background principles of law that inhere

${ }^{69}$ Compare ROBERT H. BORK, THE TEMPTING OF AMERICA: THE POLIIICAL SEDUCTION OF THE LAW 230 (1990) (asserting that Epstein's conclusions "are not plausibly related to the original understanding of the takings clause"), and Charles Fried, Protecting Property-Law and Politics, 13 HARV. J.L. \& PUB. POL'Y 44, 48-49 (1990) (arguing that Epstein distorts both Locke's theories and the Constitution), with LAURENCE H. TRIBE, AMERICAN CONSTITUTIONAL LAW § 9-6, at 606 n.6 (2d ed. 1988) ("The gaps, flawed assumptions and argumentative ellisions in Epstein's reactionary interpretation of the fifth amendment [are] too numerous to address fairly here ...."), and Douglas T. Kendall \& Charles P. Lord, The Takings Project: A Critical Analysis and Assessment of the Progress So Far, 25 B.C. ENVTL. AFF. L. REV. 509, $520-28$ (1998) (summarizing critiques of Epstein's takings theories).

${ }^{64}$ See STALEY, supra note 30, at 63 (urging the adoption of "[a] well-defined and enforceable system of property rights ${ }^{n}$ under which virtually any government action that restricts property use or diminishes property value would be deemed a compensable taking).

${ }^{65}$ See id. at 65 (arguing for nuisance-based standards for land-use regulation).

${ }^{66}$ See Private Property Rights and Environmental Laws: Hearings Before the Senate Comm. on Env't and Pub. Works, 104th Cong. 76 (1995) (statement of Joseph L. Sax, Counselor to the Secretary and Deputy Assistant Secretary for Policy, Department of the Interior) (concluding that throughout its history, "the views of the Court have been remarkably consistent over many decades on a number of central points" in takings jurisprudence, including the proposition that not all use restrictions and value losses are compensable).

${ }^{67}$ See Concrete Pipe and Prods. of Cal., Inc. v. Construction Laborers Pension Trust for S. Cal., 508 U.S. 602, 645 (1993) (unanimously concluding that "our cases have long established that mere diminution in the value of property, however serious, is insufficient to demonstrate a taking").

${ }^{69}$ See Miller v. Schoene, 276 U.S. 272, 279-80 (1928) (rejecting a standard of takings liability based on whether the challenged government action is a common law nuisance); Keystone Bituminous Coal Ass'n v. DeBenedictis, 480 U.S. 470, 490 (1987) (same) (citing Miller). 
in the title to all property held in the United States, ${ }^{69}$ the notion that all other land-use restrictions are a compensable taking has no relationship to the text of the Takings Clause or our constitutional heritage.

Some skeptics, however, are less constrained by the text, meaning, and structure of the Constitution in their efforts to use the judiciary to advance their agenda. They are candid in their call for judges to go beyond the written law by creating new law that furthers natural rights and conservative social policies. ${ }^{70}$ The arguments made against inappropriate use of the judiciary to promote liberal goals apply with equal force to these conservative activists. ${ }^{71}$

In addition to these conventional (and often compelling) objections to an imperial judiciary, unduly aggressive use of the Takings Clause in the name of "property rights" confronts a truth-in-labeling objection. Notwithstanding the rhetoric used by the so-called property rights movement, land-use controls and other community protections enhance the property rights and property values of most Americans. The overwhelming majority of property owners in the United States are homeowners (more than sixty million strong), and their property values are greatly enhanced by local zoning ordinances and other land-use controls. ${ }^{72}$ Even owners of undeveloped land are net

${ }^{69}$ See Lucas v. South Carolina Coastal Council, 505 U.S. 1003, 1027-31 (1992) (holding that even land-use regulation that completely denies the owner all use and value of the land is not a taking where it flows from "the restrictions that background principles of the State's law of property and nuisance already place upon land ownership").

See, e.g., William H. Mellor, The Quest for Justice: Natural Rights and the Future of Public Interest Law (Inaugural Speech Launching the Institute for Justice, Heritage Foundation Lecture 342, Sept. 10, 1991) (visited Oct. 27, 1999) <http://www.instituteforjustice.org/profile/speech.shtml> (defining judicial restraint as "the notion that judges are to apply the written law and not attempt to create it," concluding that "judicial restraint as an end in itself gave insufficient hope for protecting crucial rights," and calling for "a modern jurisprudence based on natural rights").

${ }^{7}$ See, e.g., LEARNED HAND, THE BILL OF RIGHTS: THE OLIVER WENDELL HOLMES LECTURES, 1958, at 70 (1958).

For myself it would be most irksome to be ruled by a bevy of Platonic Guardians, even if I knew how to choose them, which I assuredly do not. If they were in charge, I would miss the stimulus of living in a society where I have, at least Id. theoretically, some part in the direction of public affairs.

72 See Private Property Rights and Environmental Laus: Hearings Before the Senate Comm. on Env't and Pub. Works, 104th Cong. 203, 204, $207-08$ (1995) (statement of Dr. C. Ford Runge, Professor, Department of Agricultural and Applied Economics, University of Minnesota) (arguing that development restrictions benefit "the great majority of homeowners"). 
winners from government actions that affect property values. ${ }^{73}$ Inappropriate use of the Takings Clause to undermine controls on harmful land use does not promote property rights generally, but rather the rights of a select few at the expense of the majority of property owners. ${ }^{74}$ Those advocating such an application of the Clause should come clean and drop the property rights mantra.

\section{- CONCLUSION}

Smart growth initiatives raise a number of legitimate concerns. For example, some regulations imposed in the name of smart growth might implicate the availability of affordable housing. ${ }^{75}$ Other initiatives need to be examined to ensure that in addition to preventing sprawl, they concomitantly promote the redevelopment of central cities into livable communities that can absorb future growth.

It is too late in the day, however, to argue that urban sprawl is a non-issue, or worse yet that it somehow reflects the American Dream. Sprawl-promoting government subsidies and policies long have skewed the marketplace at the expense of our natural environment, our quality of life, and our sense of community. Unless we protect our remaining open spaces and remake our urban centers into desirable places to live, we can look forward to increased pollution, longer commutes, worsening road rage, more economic depression in our central cities, higher infrastructure costs and taxes, and further loss of our cultural heritage and sense of community. Nothing in our Constitution or traditions prevents us from making thoughtful choices about how and where to grow. As the Supreme Court noted long ago, "we must not forget, that the community also have rights, and that the happiness and well-being of every citizen depends on their faithful preservation." ${ }^{76}$

${ }^{73}$ See id. at 205-07 (arguing that, in general, owners of large pieces of undeveloped land benefit from government restrictions over time).

${ }^{74}$ See id. at 207-08 (arguing that loosening environmental restrictions on land use would benefit a select few, such as owners of undeveloped land, while harming the majority of homeowners who benefit from these laws).

${ }^{7}$ Cf. Todd Shields, Md. County Proposes Minimum Size for Houses, WASH. POST, Oct. 6 , 1999, at B1 (reporting that a proposed ban on single-family houses smaller than 2000 square feet, being considered "to curtail rapid, budget-busting residential growth," raised serious concerns among affordable housing advocates).

${ }^{76}$ Charles River Bridge v. Warren Bridge, 36 U.S. (11 Pet.) 420, 548 (1837). 
